\title{
Psychometric Properties of the Brief Version of the Social Skills Inventory for Adolescents
}

\author{
Vanessa Barbosa Romera Leme ${ }^{1}$, Felipe Valentini ${ }^{2}$, Josiane Rosa Campos ${ }^{3}$, Almir Del Prette ${ }^{4}$ and \\ Zilda A. P. Del Prette ${ }^{4}$ \\ 1 Universidade do Estado do Rio de Janeiro (Brazil) \\ 2 Universidade Salgado de Oliveira (Brazil) \\ ${ }^{3}$ Universidade Estadual Paulista (Brazil) \\ ${ }^{4}$ Universidade Federal de São Carlos (Brazil)
}

\begin{abstract}
The present study aimed to evaluate the evidence of internal structure and scores reliability of the Social Skills Inventory for adolescents - brief version (IHSA-Del-Prette). The following analyses were performed: (1) Exploratory Factor Analysis - EFA; (2) Confirmatory Factor Analysis - CFA; (3) Reliability; (4) Multigroup Analysis (invariance). The participants were 2,291 students of the Middle and High Schools, both sexes aged 12 to 17 years old divided into two sample groups: 1,172 participants in sample group 1 (collected 2006-2007) and 1,119 in sample group 2 (collected 2011-2012). The results of the EFA (group 1) support the four subscales structure (Self-control, Affective Approach, Empathy and Assertiveness) for 16 items (loadings > .30). The structure was confirmed by the CFA performed on the second group $(\mathrm{CFI}=.96, \mathrm{TLI}=.95, \mathrm{RMSEA}=.05,90 \% \mathrm{CI}[.04, .05]$, loadings $>.50)$; and showed scalar invariance (samples 1 and 2$)$ due to group and age, as well as partial scalar invariance due to gender $(\triangle \mathrm{CFI}<.01 ; \Delta \mathrm{NCI}<.02)$. It was concluded the brief version of IHSA-Del-Prette presents psychometric properties for use in the Brazilian context.
\end{abstract}

Received 18 July 2016; Revised 29 May 2017; Accepted 7 June 2017

Keywords: adolescence, multi-group confirmatory factor analysis, psychometric social skills.

Over the last decade several studies point to the importance of investing in the evaluation of adolescents' social skills and their interpersonal contexts, aiming at preventive interventions, the promotion of health or the treatment of various psychological disorders (Durlak, Weissberg, Dymnicki, Taylor, \& Schellinger, 2011). Social skills are understood as classes of social behavior, valued by society and essential for a socially competent performance (Del Prette \& Del Prette, 2009; 2010). Therefore, its definition is complementary to the concept of social competence (Del Prette \& Del Prette, 2005 , p. 33), understood as "the ability to articulate thoughts, feelings and actions according to personal goals and the requirements of any given situation and society, resulting in positive consequences for the individual and his relationship with other people".

When present in the skill repertoire of adolescents, social skills are protective factors (Del Prette, Del Prette, Oliveira, Gresham, \& Vance, 2012) and have been shown to be associated with healthy relationships with parents (Sabbag \& Bolsoni-Silva, 2015), the prevention of courtship violence (Murta, Del Prette, \& Del Prette, 2010, World Health Organization, 2010), good academic

Correspondence concerning this article should be addressed to Vanessa B. R. Leme. Rua Francisco Xavier, 524. $10^{\circ}$ andar - Bloco F - sala 10.122. 20550-900. Maracanã Viagem, Rio de Janeiro (Brazil). Phone: +55-2137419111.

E-mail: vanessaromera@gmail.com performance (Caemmerer \& Keit, 2015, DiPrete \& Jennings, 2012, Feitosa, Matos, Del Prette, \& Del Prette, 2009), ease in making and maintaining friendships (Glick \& Rose, 2011) and other positive indicators such as social support and well-being (Beauchamp \& Anderson, 2010; Leme, Del Prette, \& Coimbra, 2015). On the other hand, social skill deficits are associated with depression (Campos, Del Prette, \& Del Prette, 2014a, Nilsen, Karevold, Røysamb, Gustavson, \& Mathiesen, 2013), social anxiety (Stravynski, Kyparissis, \& Amando, 2014), substance abuse (Vorobjov, Saat, \& Kull, 2014) and various other psychological disorders (Del Prette, Rocha, Silvares, \& Del Prette 2012). As such, a low social skills skill set constitutes a factor of risk.

An instrument published in Brazil in 2009, the Social Skills Inventory for Adolescents, better known through the acronym IHSA-Del-Prette, has been increasingly used, with additional studies further to those referred to in the manual (Del Prette \& Del Prette, 2009), proving its psychometric properties (Campos, Del Prette, \& Del Prette, 2014b; Dascanio, Olaz, Fontaine, Del Prette, \& Del Prette, 2012; Del Prette, Rocha et al., 2012; Del Prette, Teodoro, \& Del Prette, 2014; Leme, Campos, Coimbra, Del Prette, \& Del Prette, 2016; Leme et al., 2015). Most of these studies, except for the Del Prette et al. (2014) study, did not explore the differences of social skills between gender and age-group. In the referred study, female adolescents demonstrated more social 
skills relating to empathy, assertiveness, social selfconfidence, self-control and civility than male adolescents. With regards to age, the younger adolescents showed less social skills relating to social selfconfidence and the older ones showed more self-control. Research that encompasses such differences can only be conducted if there is an assurance that the factorial structure and parameters of the items are invariant between the groups. The results of these studies provide evidence confirming the notion that the validation of psychological tools is a continuous and cumulative process, based on new studies (Borsa, Damásio, \& Bandeira, 2012).

IHSA-Del-Prette is a self-reporting tool for adolescents, with items that assess the social skills required for interpersonal situations with family, friends, people with authority, and affective partner. According to the authors of the manual (Del Prette \& Del Prette, 2009), the instrument brings together social skills such as: empathy, which includes items relating to skills in identifying other people's feelings and problems, expressing understanding and support self-control, which includes skills relating to reacting calmly in frustrating, uncomfortable, angry and humiliating situations; civility, which includes skills relating to saying goodbye, expressing thanks for favor or praise, assertiveness, which refers to the capability of dealing with situations that require standing up for one's rights and self-esteem, with the risk of the interlocutor reacting in a negative manner; affective approach, which brings together the conversational skills for relationships of friendship, sexual intimacy and expressions of affection; social self-confidence, which includes skills in presenting group work and talking to authority figures.

Given the relevance of studies on prevention and health promotion and the quality of life of adolescents (Murta et al., 2010), a greater investment in large-scale evaluations is justified. For this, it is essential to have valid and reliable instruments that can also be quickly applied and processed, as is the case of brief scales. According to Bolsoni and Zuardi (2015), these are important tools for the early identification, detection and prevention of positive and negative indicators of people's quality of life and health. And, there is also the added advantage of the brief scales enabling fast data collection, with a low monetary cost and little difficulty in answering by the respondent, further to the quick tabulation of the data and, consequently, less time until publication and the information reaching the scientific community.

The development and/or refinement of brief scales from broader instruments is consistent with the current trend of producing "leaner" scales to enable cohort studies and problem tracking (Bolsoni \& Zuardi, 2015). This requires investing in psychometric studies that allow for the identification of short scales, with acceptable validity and accuracy indicators. It is understood that, as with the complete instruments, the analysis of these properties must involve both factorial structure (exploratory and confirmatory) and reliability in terms of temporal stability and invariance, in other words, if the short scale evaluates in the same manner or if it skews the results when taking into account groups separated by gender and age-group.

Despite the importance and need for valid and reliable brief scales, the study of the psychometric qualities of such scales is still infrequent in foreign and domestic literature (Bolsoni \& Zuardi, 2015). As such, when considering the psychometric qualities already presented by the original IHSA-Del-Prette version, it is understood that a brief version of this instrument is necessary to foster relevant directions for new research in this area. Based on the previous considerations, the present study aimed to evaluate the psychometric properties of a short version of IHSA-Del-Prette. Specifically, for the short version produced here, the following are presented: (1) Exploratory Factor Analysis - EFA; (2) Confirmatory Factor Analysis - CFA; (3) Reliability; (4) Multi-group Analysis - AMG (invariance).

\section{Method \\ Participants}

Participants in the investigation were Middle and High School students $(N$ total $=2291)$, separated into two sample groups, who were assessed over an average period of five years. Group 1 (collected 2006-2007) refers to the data described in the original validation study of the IHSA-Del-Prette (Del Prette \& Del Prette, 2009), consisting of 1172 adolescents (ages between 12 and 17 years, $M=14.56$; $S D=1.65)$, of both genders $(50.30 \%$ women). Students were attending the $5^{\text {th }}(n=10,0.9 \%)$, $6^{\text {th }}(n=176,15.0 \%), 7^{\text {th }}(n=212,18.1 \%)$ and $8^{\text {th }}(n=164$, $14.0 \%)$ years of Middle Education and the $1^{\text {st }}(n=252$, $21.5 \%), 2^{\text {nd }}(n=217,18.5 \%)$ and $3^{\text {rd }}(n=141,12.0 \%)$ years of public and private High Schools in cities of the states of São Paulo, Minas Gerais and Paraná. With regards to the socio-economic level ${ }^{1}$, most of the students were grouped in classes C (25.1\%), B2 (22.8\%) and B1 (19.5\%).

Group 2 (collected 2011-2012) consisted of 1119 students, of which $581(51.9 \%)$ were female with ages between 1 and 17 years $(M=14.11, D P=1.31)$. The adolescents attended $6^{\text {th }}(n=138,12.3 \%), 7^{\text {th }}(n=318$,

\footnotetext{
${ }^{1}$ In the study, socio-economic level evaluation was undertaken based on Critério Brasil (ABEP, 2009 - http://www.abep.org/criterioBrasil. aspx), which allows for the identification of five classes based on the educational levels of the head of the family and consumer goods, arranged from greater to lesser. A (divided into A1 and A2), B (divided into B1 and B2), C, D and E.
} 
$28.4 \%)$ and $8^{\text {th }}(n=186,16.6 \%)$ years of Middle Education and the $1^{\text {st }}(n=309,27.6 \%)$ and $2^{\text {nd }}(n=168$, $15 \%$ ) years of public High Schools in cities of the states of São Paulo and Minas Gerais. With regards to socioeconomic level, most of the students were grouped in classes C (24.3\%), B2 (38.4\%) and B1 (27.1\%).

\section{Instruments}

Social Skills Inventory for Adolescents (IHSA-Del Prette). It is a self-reporting tool, developed by Del Prette and Del Prette (2009), which evaluates the social skills of adolescents aged between 12 and 17 years based on everyday situations of social interaction. The original version of the instrument consists of 38 items that take into account skills according to six subscales: (1) empathy (e.g., "When noticing that a colleague is sad or has a problem, I offer my support"); (2) selfcontrol (e.g., "I react in a calm manner when things don't turn out as I would like"); (3) civility (e.g., "When someone sets a good example, I praise them"), (4) assertiveness (e.g., "When someone asks me to do something I think is abusive, I refuse"), (5) affective approach (e.g., "When I don't want to stay with a boy/girl, I refuse, even if he/she is very insistent") and (6) social self-confidence (e.g., "At school or at work I make oral presentations whenever I'm asked"). Answers to the items are given according to a Likert five-point scale (varying between $0=$ "0-2 times" to $4=$ "9-10 times"). In the original study of the instrument, Del Prette and Del Prette (2009), using Principal Component Analysis, found satisfactory and adequate internal consistency indexes for the subscales of: empathy: $\alpha=0.82$; selfcontrol: $\alpha=0.73$; civility: $\alpha=0.75$; assertiveness: $\alpha=0,68$; affective approach: $\alpha=0.70$; social self-confidence: $\alpha=0.61$. The temporal stability analysis (precision) produced positive and significant test-retest correlations $(r=0.84 ; p<.001)$.

\section{Procedure}

The data for both sample groups was collected in the classrooms. The periods of application lasted on average 30 minutes. At the beginning of each application, the objective of the investigation was announced, data confidentiality guaranteed and the voluntary nature of participation divulged. All parents or legal guardians of the students signed and returned an Informed Consent Form. The investigations were approved by the Ethics Committee of the university where the study took place.

\section{Data Analysis}

To report on the objectives related to the latent structure study of the IHSA-Del-Prette, Exploratory Factor
Analysis, Confirmatory Factor Analysis and Invariance Analysis were carried out.

\section{Exploratory Factor Analysis}

Exploratory Factor Analysis was conducted based on polychoric correlation matrices. These matrices are more suited to ordinary scales, seeing that they focus on the frequency of the answers and not on the average of the item (Lorenzo-Seva \& Ferrando, 2006). Item parameters were estimated by means of Unweighted Least Squares (ULS) and Promax oblique rotation.

\section{Selection of factors}

Parallel analysis was used for the extraction of the number of factors. Parallel analysis was conducted using 500 estimated random matrices with real data permutation (Buja \& Eyuboglu, 1992). The results of exploratory factor analysis were based on the consolidation of the reduced version of the IHSA-Del-Prette.

\section{Confirmatory Factor Analysis and Internal Consistency}

The reduced IHSA-Del-Prette structure was also evaluated using structural equation modeling (confirmatory factor analysis). The parameters were estimated based on the polychoric correlation matrix, using the Robustus Weighted Least Squares (WLSMV) method, recommended by Muthén, du Toit, and Spisic (1997) when the data is categorical (arranged on a Likert type scale, which characterizes it as ordinal). The overall fit of the hypothesized model was evaluated based on the following set of indices and respective reference values for an acceptable fit: $\chi^{2} / \mathrm{gl}<5$ (Arbuckle, 2008); Bentler Comparative Fit Index - CFI> 0.95; Tucker-Lewis Index TLI> 0.95; Root Mean Square Error of Approximation RMSEA <0.05 (Byrne, 2012). The reliability of the IHSA-Del-Prette was evaluated by means of Composite Reliability (CC) and Average Extracted Variance (AVE). The analyses were carried out using the software Factor (version 10.3) and Mplus (version 7.1, Muthén \& Muthén, 1998/2012).

\section{Invariance Analysis}

In order to verify to what extent the short version of the IHSA-Del-Prette maintained the same subscale structure with regards to temporal stability, age-group and gender, invariance analyses of the model were undertaken using structural equation modeling. As such, observing the recommendations made by Byrne (2012), three models were tested in which the number of items and factors, (configural invariance), factor loadings (metric invariance) and thresholds (scalar invariance), were progressively constrained to be equal across groups. 
The differences between the adjustments of the most restricted and least restricted models were evaluated using $\Delta \chi^{2}$ (difference in chi-square value), $\Delta \mathrm{CFI}, \Delta \mathrm{CFI}$, Gamma-Hat (difference of the absolute GammaHat indicator), $\triangle \mathrm{NCI}$ (difference of McDonald's Non-Centrality Index), as indicated by Cheung and Rensvold (2002).

\section{Results}

\section{Exploratory Factor Analysis}

Exploratory Factor Analysis was conducted based on sample 1 of the present study. Before reducing the number of items, the preliminary subscale models were tested using this sample. In the first preliminary model, with all items, parallel analysis indicated that the percentage of variance explained by the fourth dimension with random data was higher than the one explained with empirical data (empirical data: $28.1 \%$, $7.3 \%, 5.2 \%$ and $4.5 \%$, random data: $5.6 \%, 5.4 \%, 5.1 \%$ and $5.0 \%$ ). To elaborate the second preliminary model, four items with the highest factorial loads in a single dimension (i.e., without cross loadings), and higher communalities, were chosen. As such, the second model presented 12 items contemplating the dimensions of Self-control, Affective Approach and Empathy, but excluded the Assertiveness dimension. This subscale has been associated with important indicators of positive adjustment in adolescents, such as self-esteem and well-being (Sarkova et al., 2013). Thus, a final model was tested, in which four items with the higher loadings of the Assertiveness subscale were reintroduced into the analyses. The factor loadings, communalities and eigenvalues of the final exploratory factor analysis are presented in the supplementary Table, in the appendix.

\section{Confirmatory Factor Analysis and Internal Consistency}

Confirmatory factor analyses were performed using structural equation modeling. All models were estimated based on sample 2 of the present study. Initially, an attempt was made to evaluate the fit of the final model with four dimensions and 16 items, as well as the preliminary model with three dimensions and twelve items. Both models were configured with correlated first-order factors and presented the following fit indicators: Three factor model (12 items), $\chi^{2}(g l)=215.14$ (51), TLI $=0.95, \mathrm{CFI}=0,96$, RMSEA $(90 \% \mathrm{CI})=0.05$ (0.05-0.06); four factor model (16 items), $\chi^{2}(g l)=353.85$ (98), $\mathrm{CFI}=0.96, \mathrm{TLI}=0.95, \mathrm{RMSEA}(90 \%$ IC $)=0.05$ (0.04-0.05).

It should be noted that the fit indicators of the two models cannot be compared, since they are non-nested models with different numbers of items.
Generally, however, the results indicate that both models are plausible. Additionally, the introduction of four items and one dimension was not accompanied by a drastic reduction in the quality of fit of the model. Thus, it was decided to keep the four-dimensional model for the reduction of the IHSA-Del-Prette. For model identification purposes, the variances of latent variables were set at one, so that all factor loadings could be freely estimated. Consequently, standardized and non-standardized loadings resulted in the same values. Item parameters are shown in Table 1.

The loadings average (standardized regression coefficients between items and factors) was $0.63(S D=0.09)$. However, ten factor loadings presented values lower than 0.70 , reducing the reliability of the latent scores. The correlations between the factors were moderate, indicating that a significant part of score variance is shared among the factors.

Regarding the endorsement of the categories, the thresholds, presented in Table 1, point to relatively easy items. For most items, participants, with a latent score only a standard deviation above the average, tend to endorse the higher Likert category. In Table 1, the values for average variance extracted (AVE) are also shown. It was found that the variances shared between the dimensions (determination coefficients) are smaller than the AVE. These results evidence the discriminant validity of the four factorial scores.

AVE was also used to evaluate internal consistency. Considering it is a reduced instrument that has few items, the AVE was expected to be greater than 0.49 . With regards to the empathy and assertiveness factors, the higher factorial loads supported AVE values near the cut-off point. With regards to the self-control and affective approach factors, the AVE values are minimally acceptable, even though lower than expected, seeing that the factorial load averages of these factors were 0.58 and 0.60 , respectively.

Still with regards to internal consistency, the composite reliability (CC) values were: 0.66 for self-control scores; 0.69 for affective approach; 0.78 for empathy; and 0.75 for assertiveness. These values, close to or higher than 0.70 , also show evidence of internal consistency and scores reliability, when considering the reduced number of items, seeing that CC tends to result in single values due the few items.

\section{Invariance Analysis}

Based on the evidence of the four-dimensional structure of the reduced version of the inventory, it was sought to evaluate the invariance of the parameters among the different databases (consisting of samples from different years), age-group (12 to 14 years and 15 to 17 years) and gender, by means of multi-group 
Table 1. Synthesis of the Confirmatory Factor Analysis Results $(n=1119)$

\begin{tabular}{|c|c|c|c|c|c|c|}
\hline \multirow[b]{2}{*}{ Dimensions } & \multirow[b]{2}{*}{ Items } & \multirow[b]{2}{*}{$\beta(\mathrm{SE})$} & \multicolumn{4}{|c|}{ Threshold } \\
\hline & & & $\delta_{1}$ & $\delta_{2}$ & $\delta_{3}$ & $\delta_{4}$ \\
\hline Affective Approach & $\rightarrow \mathrm{I} 10$ & $0.50(0.03)$ & -0.20 & 0.23 & 0.81 & 1.29 \\
\hline Affective Approach & $\rightarrow \mathrm{I} 13$ & $0.70(0.03)$ & -1.11 & -0.67 & 0.04 & 0.75 \\
\hline Affective Approach & $\rightarrow \mathrm{I} 25$ & $0.56(0.03)$ & -0.92 & -0.43 & 0.30 & 1.02 \\
\hline Affective Approach & $\rightarrow \mathrm{I} 37$ & $0.65(0.03)$ & -0.75 & -0.26 & 0.54 & 1.12 \\
\hline Self-control & $\rightarrow \mathrm{I} 8$ & $0.54(0.03)$ & -0.98 & -0.53 & 0.00 & 0.59 \\
\hline Self-control & $\rightarrow \mathrm{I} 14$ & $0.60(0.03)$ & -0.75 & -0.30 & 0.25 & 0.82 \\
\hline Self-control & $\rightarrow \mathrm{I} 30$ & $0.72(0.03)$ & -1.00 & -0.47 & 0.21 & 0.90 \\
\hline Self-control & $\rightarrow \mathrm{I} 38$ & $0.45(0.03)$ & -0.41 & -0.06 & 0.44 & 0.99 \\
\hline Empathy & $\rightarrow \mathrm{I} 7$ & $0.62(0.02)$ & -1.67 & -1.24 & -0.57 & 0.37 \\
\hline Empathy & $\rightarrow \mathrm{I} 19$ & $0.73(0.02)$ & -1.39 & -1.09 & -0.50 & 0.30 \\
\hline Empathy & $\rightarrow \mathrm{I} 28$ & $0.66(0.02)$ & -1.56 & -1.22 & -0.71 & 0.15 \\
\hline Empathy & $\rightarrow \mathrm{I} 34$ & $0.73(0.02)$ & -1.41 & -1.04 & -0.50 & 0.44 \\
\hline Assertiveness & $\rightarrow \mathrm{I} 11$ & $0.60(0.03)$ & -1.37 & -0.96 & -0.22 & 0.50 \\
\hline Assertiveness & $\rightarrow \mathrm{I} 12$ & $0.60(0.03)$ & -1.18 & -0.79 & -0.21 & 0.41 \\
\hline Assertiveness & $\rightarrow \mathrm{I} 15$ & $0.72(0.03)$ & -1.24 & -1.01 & -0.46 & 0.13 \\
\hline Assertiveness & $\rightarrow \mathrm{I} 23$ & $0.73(0.02)$ & -1.30 & -0.94 & -0.35 & 0.32 \\
\hline
\end{tabular}

Correlations, Coefficients of Determination ${ }^{a}$ and $A V E$

\begin{tabular}{llllll}
\hline & 1 & 2 & 3 & 4 & AVE \\
\hline 1. Affective Approach & & 0.21 & 0.29 & 0.21 & 0.37 \\
2. Self-control & 0.46 & & 0.30 & 0.25 & 0.34 \\
3. Empathy & 0.54 & 0.55 & 0.42 & 0.47 \\
4. Assertiveness & 0.46 & 0.50 & & 0.44 \\
\hline
\end{tabular}

Note: ${ }^{a}=$ determination coefficients (i.e., squared loading) are presented in italics; $\beta=$ standardised and non-standardized coefficient (latent variable variance was set at 1 ); $\mathrm{SE}=$ standard error of estimate; $\delta=$ threshold between categories; $\mathrm{AVE}=$ average variance extracted.

analyses. For this, the total database, consisting of the two samples of the present study $(N=2291)$, was used. The results for the multi-group analyses are shown in Table 2.

With regards to the groups divided by databases and age groups, the parameters of the items presented invariance. The fit differences, evaluated by the chisquared test, were statically significant between the Metric model and the Scalar model, however the differences in CFI were small and lower than 0.01. Additionally, the differences of the McDonald's index $(\triangle \mathrm{NCI})$ were lower than 0.02 , which also denotes the invariance of the parameters. Though, Gamma-hat differences were slightly higher than 0.001 . Thereby, the fit indices yielded diverging conclusions: CFI and NCI indicated invariance, Gamma-hat presented borderline results, and the chi-squared test rejected the model in which the thresholds were defined as invariant between the groups. It should be noted, however, that the chi-squared test is sensitive due to sample size. Additionally, when comparing the scalar and configural model adjustments, the critical difference ratio is less than 2 (for the database, $\Delta \chi^{2} / \Delta g l=$ $(907.9-828.5) /(252-196)=1.42$; for the age-group, $\left.\Delta \chi^{2} / \Delta g l=(885.5-784.0) /(252-196)=1.81\right)$. In summary, there is evidence of the invariance of the parameters for the time (database) and for the age-group.

Regarding the gender variable, the multi-group analysis did not indicate any invariance of the thresholds, seeing that the scalar model presented a lower fit to the data when compared to the metric model. To expand this analysis, it was verified that only items 10 and 15 showed differences above 0.30 between the thresholds of the male and female groups (item 10, female: $\delta_{1}=-0.01, \delta_{2}=0.43, \delta_{3}=0.97, \delta_{4}=1.41$; item 10 , male: $\delta_{1}=-0.38, \delta_{2}=0.04, \delta_{3}=0.52, \delta_{4}=1.06$; item 15, female: $\delta_{1}=-1.34, \delta_{2}=-1.02, \delta_{3}=-0.58, \delta_{4}=-0.04$; item 15 , male: $\left.\delta_{1}=-1.42, \delta_{2}=-1.00, \delta_{3}=-0.40, \delta_{4}=0.23\right)$. Considering that the thresholds are associated with the probability of endorsement, the results showed that girls require a latent score greater than the boys to endorse the high categories of item 10, and a lower 
Table 2. Invariance Analysis - Multi-Group Confirmatory Factor Analysis $(N=2291)$

\begin{tabular}{|c|c|c|c|c|c|c|c|c|}
\hline & $\chi^{2}(g l)$ & $\Delta \chi^{2}(\Delta g l)$ & CFI & $\Delta \mathrm{CFI}$ & Gamma & $\Delta$ Gamma & NCI (Mc) & $\triangle \mathrm{NCI}(\mathrm{Mc})$ \\
\hline \multicolumn{9}{|l|}{ Database } \\
\hline Configural & 828.51 (196) & & 0.945 & & 0.967 & & 0.871 & \\
\hline Metric & $809.52(208)$ & $-18.99(12)$ & 0.948 & 0.003 & 0.968 & 0.001 & 0.877 & 0.006 \\
\hline Scalar & $907.94(252)$ & $98.42(44)^{*}$ & 0.943 & -0.005 & 0.965 & -0.003 & 0.867 & -0.01 \\
\hline \multicolumn{9}{|l|}{ Age Group } \\
\hline Configural & 784.02 (196) & & 0.946 & & 0.969 & & 0.879 & \\
\hline Metric & 775.03 (208) & $-8.99(12)$ & 0.948 & 0.002 & 0.970 & 0.001 & 0.883 & 0.004 \\
\hline Scalar & $885.45(252)$ & $110.42(44)^{*}$ & 0.942 & -0.006 & 0.966 & -0.004 & 0.870 & -0.013 \\
\hline \multicolumn{9}{|l|}{ Gender } \\
\hline Configural & 760.13 (196) & & 0.949 & & 0.970 & & 0.884 & \\
\hline Metric & 790.05 (208) & $29.92(12)^{*}$ & 0.948 & -0.001 & 0.969 & -0.001 & 0.881 & -0.003 \\
\hline Scalar & $970.77(252)$ & $180.72(44)^{*}$ & 0.935 & -0.013 & 0.962 & -0.007 & 0.855 & -0.026 \\
\hline Partial Scalara & $805.42(244)$ & $15.37(36)^{b}$ & 0.949 & $0.001^{b}$ & 0.970 & 0.001 & 0.884 & 0.003 \\
\hline
\end{tabular}

Note: $\alpha$ = thresholds of items 10 to 15 freely estimated between genders male and female; $b=$ differences between Partial Scalar and Metric models.

$*(p<.05)$.

latent score to endorse the higher categories of item 15. It should be noted that the differences are greater for item $10(\Delta \delta>0.3)$ and smaller for item 15.

\section{Discussion}

Research has shown that social skills prevent socialemotional difficulties and psychopathological disorders during adolescence and other phases of the life cycle, as well as being associated with higher levels of self-esteem, well-being and academic performance (Beauchamp \& Anderson, 2010; Caemmerer \& Keit, 2015; Durlak et al., 2011; Feitosa et al., 2009; Leme et al., 2015). On the other hand, there is a lack of instruments containing evaluated psychometric properties that seek to investigate the repertoire of social skills during adolescence. In this context, there is still no brief scale relating to the social skills of adolescents in Brazil. This type of instrument, underinvestigated in a national and international context, makes it possible to collect data more quickly and economically in order to identify resources and behavioral deficits (Bolsoni \& Zuardi, 2015). The present study evaluated the psychometric properties of a short version of the Social Skills Inventory for Adolescents - IHSADel-Prette (Del Prette \& Del Prette, 2009), whose full scale possesses satisfactory psychometric indicators.

The data obtained during the present study indicates the feasibility of the IHSA-Del-Prette brief scale, with good psychometric properties. It can be emphasized that the first preliminary model and the parallel analysis do not make the structure of the original instrument and its factors impracticable, and they could be resumed at a later stage with smaller subsamples, both in intervention and in more detailed evaluations.
The EFA and CFA results confirmed the theoretical model underlying the short version of IHSA-Del-Prette. The reduced instrument consisted of 16 items that took into account important social performance factors during adolescence, namely: self-control, affective approach, empathy and assertiveness. The items of the civility and social resource factors, present in the original instrument, are somehow contemplated in the dimensions of the brief scale. These dimensions are relevant for a healthy family relationship and help deal with peer pressure and bullying situations, thus promoting conflict resolution in a school setting (Feitosa et al., 2009; Leme et al., 2015; Sarkova et al., 2013).

Nevertheless, the results suggest some limitations and point to future research in improving the short scale and its more effective use. With regards to factorial load averages of the reduced version, it was verified that 10 items produced values lower than 0.70 , which reduce the reliability of the latent scores estimation. Such results were already expected, seeing that reduced scales tend to shrink the reliability and are not suitable for clinical diagnosis, but rather for rapid assessment and screening in wide ranging surveys. Additionally, the reliability presented on the present study is compatible with those presented in previous full-scale studies ( $\alpha$ between 0.62 and 0.82 in Del Prette \& Del Prette, 2009, $\alpha$ between 0.63 and 0.82 in Campos et al., 2014b). Therefore, it is also suggested that, during research that seeks to compare groups or relate social skills to other variables, latent modelling should be used, seeing that, in that analysis set, the imprecision of the scores is weighted during parameter estimation of the relationships between variables. 
It should be noted that the brief scale, by itself, has not yet been applied. In the two samples of the present study, only the full scale was used and, therefore, the comparison of results obtained with the original scale and the brief scale on the same sample of respondents has not yet been tested. In this sense, although unlikely, it is important to assess whether the items presented only in the brief structure maintain the same structure or infringe on the assumption of local independence.

Database and age-group invariance was verified. These results indicate that the scale presented with a stable structure over time (group 1: 2006-2007, group 2: 2011-2012), considering that the period between data collections was five years. Additionally, parameter invariance by age-group allows for the comparison between scores of adolescents of different ages.

However, the results indicated that there was no invariance with regards to gender, especially for items 10 (girls <boys) and 15 (boys < girls). Item 10 relates to the social skill (affective approach) of adolescents in expressing an interest in a person when they have the opportunity. Item 15 refers to the social skill (assertiveness) of adolescents in refusing a person's insistent request to "go out with" them. It can be assumed that item 10 is more difficult to be observed in girls and item 15 more difficult in boys, due to the influence of the gender roles reproduced in our culture. In general, women are induced to be passive in romantic relationships (Murta et al., 2010; Schäfer, 2008), while men are encouraged to be active and not very discriminate, i.e., they must seek romantic situations, even though they are unwilling, so as not to invalidate their masculinity before their peers (Straus, 2011).

As such, future studies can compare the social skills of boys and girls and, if possible, consider the difference in endorsement difficulty. Otherwise, any differences may be attributed, in part, to the differences between how answers are provided in the scale and not to the real differences between boys and girls. However, it should be noted that the differences found in relation to gender were relatively small and limited to two items, which does not, in all probability, invalidate the analyses of differences between genders already made in the literature. In conclusion, the results showed that the IHSA-Del-Prette brief scale demonstrated very satisfactory psychometric properties, by which its use is recommended in future studies relating to the social skills of adolescents. Several researchers have pointed out the importance of parents, teachers and psychologists favoring the development of social skills in order to prevent interpersonal and socio-affective difficulties or to promote mental health in adolescents (Del Prette, Rocha et al., 2012; Durlak et al., 2011).

\section{References}

Arbuckle J. L. (2008). Amos 17 users' guide. Chicago, IL: SPSS.

Associação Brasileira de Empresas de Pesquisa [ABEP] (2009). Questionário Critério Brasil. Dados com base no Levantamento Socioeconômico de 2009 [Data based on the Socioeconomic Survey 2009]. Retrieved from ABEP Website http://www.abep.org/criterio-brasil

Beauchamp M. H., \& Anderson V. (2010). Social: An integrative framework for the development of social skills. Psychological Bulletin, 136(1), 39-64. https:/ / doi. org/10.1037/a0017768

Bolsoni L. M., \& Zuardi A. W. (2015). Psychometric studies of brief screening tools for multiple mental disorders. Journal Brasileiro de Psiquiatria, 64(1), 63-69. https:/ / doi. org/10.1590/0047-2085000000058

Borsa J. C., Damásio B. F., \& Bandeira D. R. (2012). Adaptação e validação de instrumentos psicológicos entre culturas: Algumas considerações [Cross-cultural adaptation and validation of psychological instruments: Some considerations]. Paidéia, 22, 423-432. https: / dx.doi. org/10.1590/S0103-863X2012000300014

Buja A., \& Eyuboglu N. (1992). Remarks on parallel analysis. Multivariate Behavioral Research, 27, 509-540. https://doi.org/10.1207/s15327906mbr2704_2

Byrne B. M. (2012). Structural equation modeling with Mplus: Basic concepts, applications, and programming. New York, NY: Taylor \& Francis. Enders, C.K.

Campos J. R., Del Prette A., \& Del Prette Z. A. P. (2014a). Habilidades sociais e depressão na adolescência: Uma revisão da literatura [Social skills and depression in adolescence: A literature review]. Acta Comportamentalia, 22, 469-482. http: / / www.revistas.unam.mx/index.php/ acom/article/viewFile/48986/44052

Campos J. R., Del Prette A., \& Del Prette Z. A. P. (2014b). Depressão na adolescência: Habilidades sociais e variáveis sociodemográficas como fatores de risco/proteção [Depression in adolescence: Social skills and sociodemographic variables as risk factors/protection]. Estudos e Pesquisas em Psicologia, 14, 408-428. http:/ /www. e-publicacoes.uerj.br/index.php/revispsi/article/view / $12645 / 9820$

Caemmerer J. M., \& Keith T. Z. (2015). Longitudinal, reciprocal effects of social skills and achievement from kindergarten to eighth grade. Journal of School Psychology, 53, 265-281. https://doi.org/10.1016/j.jsp.2015.05.001

Cheung G. W., \& Rensvold R. B. (2002). Evaluating Gooness-of-Fit for testing measurement invariance. Structural Equation Modeling, 9, 233-255.

Dascanio D., Olaz F. O., Fontaine A. M. G., Rodrigues O. M. P. R., Del Prette A., \& Del Prette Z. A. P. (2012). The intellectual and academic performance of adolescents contaminated by lead: Relation with social skills. Temas em Psicologia, 20(1), 45-59. http:/ / pepsic.bvsalud.org/pdf/ tp/v20n1/v20n1a05.pdf

Del Prette A., \& Del Prette Z. A. P. (2009). Inventário de Habilidades Sociais para Adolescentes (IHSA-Del Prette): Manual de aplicação, apuração e interpretação [Social Skills Inventory for Adolescents (IHSA-Del Prette): Application, 
verification and interpretation Manual]. São Paulo, Brazil: Casa do Psicólogo.

Del Prette Z. A. P., \& Del Prette A. (2005). Psicologia das habilidades sociais na infância: Teoria e Prática [Psychology of social skills in childhood: Theory and practice]. Petrópolis, Brazil: Vozes (Voices).

Del Prette Z. A. P., \& Del Prette A. (2010). Social skills and behavior analysis: Historical proximity and new issues. Perspectivas em Análise do Comportamento, 1, 104-115. http://media.wix.com/ugd/89bfd6_ ad8b815844a44ccfa667cb38495fe505.pdf

Del Prette Z. A. P., Del Prette A., Oliveira L. A. D., Gresham F. M., \& Vance M. J. (2012). Role of social performance in predicting learning problems: Prediction of risk using logistic regression analysis. School Psychology International Journal, 33, 615-630. https://doi.org/ 10.1177/0020715211430373

Del Prette Z. A. P., Rocha M. M., Silvares E. F. M., \& Del Prette A. (2012). Social skills and psychological disorders. Universitas Psychologica, 11, 941-955. http:/ / revistas. javeriana.edu.co/index.php/revPsycho/article/ view/941

Del Prette Z. A. P., Teodoro M., \& Del Prette A. (2014). Social skills of adolescents: Convergent validity between IHSA-Del-Prette and Messy. Estudos de Psicologia (Campinas), 31(1), 15-24. https:/ / doi.org/10.1590/ 0103-166X2014000100002

DiPrete T. A., \& Jennings J. L. (2012). Social and behavioral skills and the gender gap in early educational achievement. Social Science Research, 41(1), 1-15. https:/ / doi.org/10.1016/j.ssresearch.2011.09.001

Durlak J. A., Weissberg R. P., Dymnicki A. B., Taylor R. B., \& Schellinger K. B. (2011). The impact of enhancing students' social and emotional learning: A meta-analysis of school-based universal interventions. Child Development, 82(1), 405-432. https://doi.org/10.1111/j.1467-8624. 2010.01564.x

Feitosa F. B., Matos M. G., Del Prette Z. A. P., \& Del Prette A. (2009). Desempenho acadêmico e interpessoal em adolescentes portugueses [Interpersonal and academic achievement of portuguese adolescents]. Psicologia em Estudo, 14, 259-266. https:/ / doi.org/10.1590/ S1413-73722009000200006

Glick G. C., \& Rose A. J. (2011). Prospective associations between friendship adjustment and social strategies: Friendship as a context for building social skills. Developmental Psychology, 47, 1117-1132. https://doi.org/ 10.1037 / a0023277

Leme V. B. R., Campos J. R., Coimbra S., Del Prette A., \& Del Prette Z. A. P. (2016). Social skills inventory for adolescents (IHSA-Del-Prette): Evidence of construct validity and reliability. PSICO, 47, 169-178.

Leme V. B. R., Del Prette Z. A. P., \& Coimbra S. (2015). Social skills, social support and well-being by adolescent of different family configurations. Paideia, 25, 9-17. https:/ /doi.org/10.1590/1982-43272560201503

Lorenzo-Seva U., \& Ferrando P. J. (2006). FACTOR: A computer program to fit the exploratory factor analysis model. Behavior Research Methods, 38(1), 88-91. https:/ / doi. org/10.3758/BF03192753
Murta S. G., Del Prette A., \& Del Prette Z. A. P. (2010). Prevenção ao sexismo e ao heterossexismo entre adolescentes: Contribuições do treinamento em habilidades de vida e habilidades sociais [Prevention of sexism and heterosexism among adolescents: Contributions of life skills and social skills training]. Revista de Psicologia da Criança e do Adolescente, 1, 73-86. http://revistas.lis.ulusiada.pt/index.php/rpca/article/ view $/ 21 /$ pdf

Muthén B., du Toit S. H. C., \& Spisic D. (1997). Robust inference using weighted least squares and quadratic estimating equations in latent variable modeling with categorical and continuous outcomes. Retrieved from Mplus Website http:/ / www.statmodel.com/download/ Article_075.pdf

Muthén L., \& Muthén B. (1998/2012). Mplus user's guide. ( $7^{\text {th }}$ Ed.). Los Angeles, CA. Author.

Nilsen W., Karevold E., Røysamb E., Gustavson K., \& Mathiesen K. S. (2013). Social skills and depressive symptoms across adolescence: Social supports a mediator in girls versus boys. Journal of Adolescence, 36(1), 11-20. https://doi.org/10.1016/j.adolescence.2012.08.005

Sabbag G. M., \& Bolsoni-Silva A. T. (2015). Interações entre mães e adolescentes e os problemas de comportamento [Interaction among mothers and adolescent and behavior problems]. Arquivos Brasileiros de Psicologia, 67(1), 68-83. http:/ / seer.psicologia.ufrj.br/index.php/abp/article/ view /886/922

Sarkova M., Bacikova-Sleskova M., Orosova O., Geckova A. M., Katreniakova Z., Klein D., \& van Dijk J. P. (2013). Associations between assertiveness, psychological well-being, and self-esteem in adolescents. Journal of Applied Social Psychology, 43(1), 147-154. https://doi. org/10.1111/j.1559-1816.2012.00988.x

Stravynski A., Kyparissis A., \& Amando D. (2014). Social phobia as a deficit in social skills. In S. M. Hofmann \& P. M. DiBartolo (Eds.), Social anxiety clinical, developmental, and social perspectives (pp. 189-225). Amsterdam, The Netherlands: Elsevier.

Straus M. A. (2011). Gender symmetry and mutuality in perpetration of clinical-level partner violence: Empirical evidence and implications for prevention and treatment. Aggression and Violent Behavior, 16, 279-288. https://doi. org/10.1016/j.avb.2011.04.010

Schäfer G. (2008). Romantic love in heterosexual relationships: Women's experiences. Journal of Social Sciences, 16, 187-197. http: / / www.krepublishers. com/02-Journals/JSS/JSS-16-0-000-000-2008-Web / JSS-16-3-000-000-2008-Abst-Text/JSS-16-3-187-08-625Schafer-G/JSS-16-3-187-08-625-Schafer-G-Tt.pdf

Vorobjov S., Saat H., \& Kull M. (2014). Social skills and their relationship to drug use among 15-16-year-old students in Estonia: An analysis based on the ESPAD data. Nordic Studies on Alcohol and Drugs, 31, 401-412. https: / / doi.org/10.2478/nsad-2014-0031

World Health Organization (2010). Preventing intimate partner and sexual violence against women: Taking action and generation evidence. Geneva, Switzerland: WHO. Retrieved from http://www.who.int/violence_injury_prevention / publications/violence/9789241564007_eng.pdf 


\section{Appendix}

Supplementary Table

Exploratory Factor Analysis and correlations between IHSA-Del-Prette ( $n=1172)$

\begin{tabular}{|c|c|c|c|c|}
\hline Item & Self-control & Affective Approach & Empathy & Assertiveness \\
\hline 8 & 0.46 & -0.06 & 0.06 & 0.14 \\
\hline 14 & 0.42 & -0.02 & 0.01 & 0.26 \\
\hline 30 & 0.69 & 0.01 & 0.06 & -0.01 \\
\hline 38 & 0.55 & 0.11 & -0.04 & -0.10 \\
\hline 10 & 0.08 & 0.62 & -0.18 & -0.01 \\
\hline 13 & -0.10 & 0.46 & 0.19 & 0.20 \\
\hline 25 & -0.08 & 0.45 & 0.19 & 0.10 \\
\hline 37 & 0.07 & 0.64 & 0.07 & -0.04 \\
\hline 7 & 0.02 & 0.07 & 0.52 & -0.02 \\
\hline 19 & 0.05 & -0.02 & 0.50 & 0.23 \\
\hline 28 & 0.15 & 0.03 & 0.46 & 0.07 \\
\hline 34 & 0.01 & 0.00 & 0.82 & -0.04 \\
\hline 11 & -0.01 & 0.20 & 0.00 & 0.39 \\
\hline 12 & 0.06 & 0.03 & -0.08 & 0.52 \\
\hline 15 & -0.02 & -0.02 & 0.04 & 0.63 \\
\hline 23 & 0.07 & 0.04 & 0.08 & 0.46 \\
\hline \multicolumn{5}{|c|}{ Correlations between factors } \\
\hline & $\mathrm{F} 1$ & $\mathrm{~F} 2$ & F3 & $\mathrm{F} 4$ \\
\hline \multicolumn{5}{|l|}{$\mathrm{F} 1$} \\
\hline $\mathrm{F} 2$ & 0.31 & & & \\
\hline F3 & 0.25 & 0.23 & & \\
\hline $\mathrm{F} 4$ & 0.23 & 0.26 & 0.49 & \\
\hline
\end{tabular}

